\title{
Twin Roll Casting of Aluminum Alloy AC7A Using Commercial Scale Machine
}

\author{
Makoto Hagiwara $^{1}$, Shinichi Nishida ${ }^{1, *}$, Daichi Uematsu ${ }^{1}$, Shogo Imai ${ }^{1}$, \\ Mizuki Kawawa $^{1}$, Kyohei Ogawa ${ }^{1}$, Takahiro Shiga ${ }^{1}$ and Toshio Haga ${ }^{2}$
}

\author{
${ }^{1}$ Department of Mechanical Science and Technology, Gunma University, Japan \\ *Email: snishida@gunma-u.ac.jp \\ ${ }^{2}$ Osaka Institute of Technology, Japan
}

Received: 18 Nov 2020; Received in revised form: 06 Dec 2020; Accepted: 15 Dec 2020; Available online: 21 Dec 2020

(C)2020 The Author(s). Published by Infogain Publication. This is an open access article under the CC BY license

(https://creativecommons.org/licenses/by/4.0/).

\begin{abstract}
Twin roll casting process is able to produce a strip from molten metal directly. Thus this process has a possibility to reduce total cost of sheet making comparing to conventional rolling process. Strip casting process has some disadvantages. Casting speed depends on the material properties. It is difficult to determine the casting conditions. Twin roll casting of aluminum alloy AC7A using commercial scale machine was operated. The aims of this study is to investigate the effect of the roll speed. Continuous strip could not be produced at the roll speed $5 \mathrm{~m} / \mathrm{min}$. Continuous strip could be produced at the roll speed $10 \mathrm{~m} / \mathrm{min}$. However, cracks were observed. Continuous strip could be produced at the roll speed $20 \mathrm{~m} / \mathrm{min}$. However, cracks were observed too.
\end{abstract}

Keywords-Vertical type twin roll casting process, Aluminum alloy AC7A, Castability, Surface condition, Strip thickness.

\section{INTRODUCTION}

It is important that the improvement of fuel efficiency of transport machine such as automobile through the viewpoint of the global environment and the resource protection. The methods of improving fuel efficiency are the several ways such as improving of power drive system and reduction of running resistance and weight. Among them, weight saving of car weight is an effective method of improving fuel efficiency. Therefore, Aluminum for car structural material is attracted attention from the point of the weight reduction. The demand of aluminum is increasing for recent years in Japan. Especially the demand of aluminum for transport machine is increasing in last years.[1], [2] Therefore, it is necessary to reduce the cost of manufacturing Aluminum strip.

This paper describes a vertical type twin roll strip casting process for producing aluminum alloy strip of AC7A. Aluminum strip[2] is generally produced by multi process such as DC casting, scalping, hot rolling of $200 \mathrm{~mm} \sim 600$ $\mathrm{mm}$ thickness slab, repeated cold rolling and annealing.
Form the above, the manufacturing cost of Aluminum strip become high because of the number of processes.

The vertical twin roll strip caster was used in this study. It is possible to produce an Aluminum strip continuously from molten metal directly by twin roll strip casting. The molten metal was solidified on the roll surface and formed to strip. Strip thickness is about $1 \sim 3 \mathrm{~mm}$. Strip casting process is a rapid cooling solidification process. So that the mechanical properties improve. The roll speed is generally high in twin roll casting such as $60 \sim 150 \mathrm{~m} / \mathrm{min}$. Thus, it is possible to reduce the strip manufacturing cost compared with the conventional rolling process because of the highly productivity. Strip casting process has some disadvantages. Casting speed depends on the material properties. It is difficult to determine the casting conditions.

A lot of study of twin roll casting is reported [3]-[10]. For the purpose of practical application of strip casting, this paper carried out the research of vertical twin roll strip casting of aluminum alloy AC7A using a large equipment. In this report, the effect of the roll speed was investigated. 
The continuity, surface properties, thickness of the strips and microstructures were evaluated.

\section{EXPERIMENTAL DEVICES AND CONDITIONS}

Fig. 1 (a), (b) and (c) show photographs of the experimental apparatus. Fig. 1 (a) is a front view of the device. Fig. 1 (b) is a top view. Fig. 1 (c) is an overall view. This device was manufactured by IHI Co., Ltd. and transferred to Gunma University Ota Campus. This device was manufactured for magnesium alloys. In this time, some modifications were made in conducting experiments on aluminum alloys. The roll material is SKD 61, the roll diameter is $1,000 \mathrm{~mm}$, the roll width is $240 \mathrm{~mm}$, it is a solid material. The maximum rolling load on the design is 75 tons, and it is possible to apply loads up to $312.5 \mathrm{kgf} /$ $\mathrm{mm}$ when converted per unit width. The roll gap is fixed type. The roll speed is variable using an inverter and can be varied from $3 \mathrm{~m} / \mathrm{min}$ to $100 \mathrm{~m} / \mathrm{min}$. The capacity of the motor is 3 phases $400 \mathrm{~V}, 80 \mathrm{~kW}$, and the roll is rotated through the gear box and the universal joint. Fig. 2 shows a photograph of the load cell. Two load cells are installed and it is possible to successively measure the rolling load during twin roll casting that changes every minute. In this study, only the maximum load in the experiment is shown. Fig. 3 shows a photograph of the side dam. The side dam is formed from a mild steel strip and five layers of heat resistant cloth. Heat resistant cloth was pasted to mild steel strip using spray glue (3M, 88). Approximately $2 \mathrm{~kg}$ of AC7B alloy was melted in a crucible furnace. Fig.4 shows a photograph of the pouring mechanism. We installed a wire in the crucible box and pour the molten metal by tilting the box by pulling the wire from the mezzanine level of the laboratory for safety. Fig. 5 shows a photograph of the nozzles. The nozzle is formed of stainless plate, heat-resistant cloth and carbon sheet. The nozzle was used to control the solidification distance. A graphite spray (Fine Chemical Japan Co., Ltd.) was used as the release agent for the roll. The experimental conditions are shown in Table 1. The initial roll gap was $1.5 \mathrm{~mm}$. The roll gap was adjusted by tightening the nut and checked with a thickness gauge. The solidification length was $100 \mathrm{~mm}$. In the preliminary experiment, the pouring temperature was set at $640^{\circ} \mathrm{C}\left(5^{\circ} \mathrm{C}\right.$ on the liquidus temperature). The roll speeds were $5 \mathrm{~m} / \mathrm{min}, 10$ $\mathrm{m} / \mathrm{min}$, and $20 \mathrm{~m} / \mathrm{min}$.

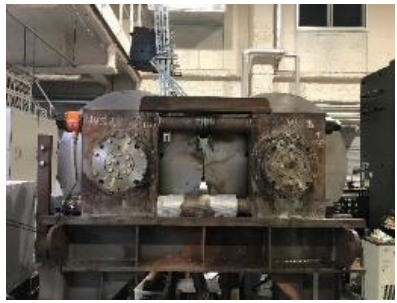

(a) Front view

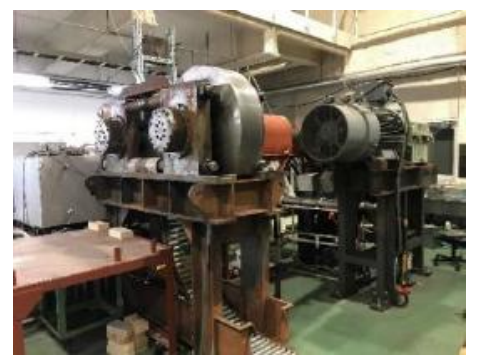

(c) Overall view

Fig. 1 Twin roll strip casting machine

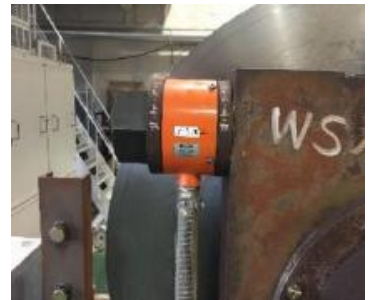

Fig.2 Load cell

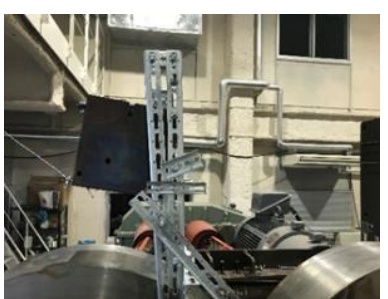

Fig. 4 Pouring device

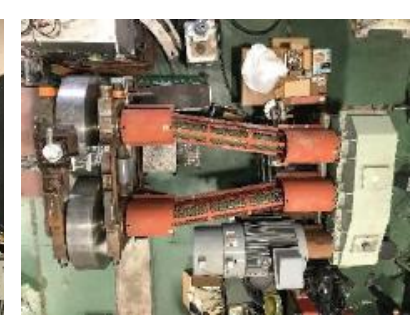

(b) Top view

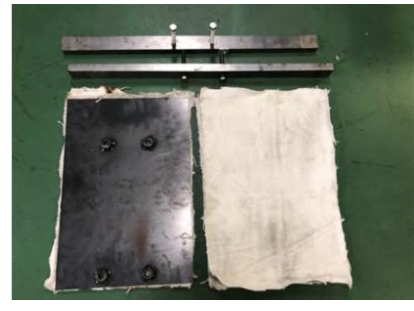

Fig.3 Side dam plates

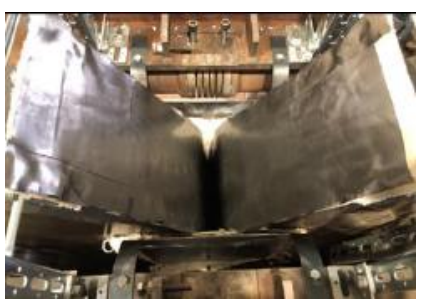

Fig. 5 Nozzles
Table 1 Experimental conditions

\begin{tabular}{l|c}
\hline \hline Material & AC7A \\
\hline Pouring temperature $\left[{ }^{\circ} \mathrm{C}\right]$ & 640 \\
\hline Initial roll gap [mm] & 1.5 \\
\hline Solidification length [mm] & 100 \\
\hline Roll speed [m/min] & $5,10,20$ \\
\hline
\end{tabular}

\section{RESULTS AND DISCUSSION}

Fig. 6 (a), (b) and (c) show the strips. Table 2 shows the measurement results of the thickness, length and maximum 
load of the strips. The strips' width coincided with the roll width. No cracks were observed in the strip with the roll speed of $5 \mathrm{~m} / \mathrm{min}$, and the surface properties had metallic luster. In the strip of $10 \mathrm{~m} / \mathrm{min}$, the surface condition consisted of metallic luster part and opaque part. Fig. 7 shows an enlarged photograph of the strip with a roll speed of $10 \mathrm{~m} / \mathrm{min}$. The solidification cracks occurred in the cloudy part. In the cloudy part, the contact with the roll was insufficient. Therefore, the cooling of the strip was insufficient, and the cracks seemed to have occurred because of the tensile load by the roll rotation without completing the solidification. In the strip with the roll speed of $20 \mathrm{~m} / \mathrm{min}$, the surface property was mainly composed of the cloudy part. There was a difference between the roll speed and the discharge speed of the strip. Therefore, it is considered that the gap was not filled sufficiently with the molten metal. The solidification cracks were observed too. The cause of the difference between the initial roll gap and the plate thickness is the problem of the degree of mastery of the equipment, and it is considered that this problem can be solved by setting the initial roll gap for the target plate thickness in consideration of elastic deformation of the equipment. Continuous strips could be produced at a roll speed of 10 $\mathrm{m} / \mathrm{min}$ and $20 \mathrm{~m} / \mathrm{min}$. At a roll speed of $5 \mathrm{~m} / \mathrm{min}$, it became the limit load of the apparatus, and it was impossible to make continuous strips because the roll stopped. Fig. 8 shows the results of microstructural observations at a circumferential speed of $10 \mathrm{~m} / \mathrm{min}$. More crystallites and precipitates were observed in the center of the rolls than near the surface. It was thought that a supersaturated $\alpha$-Al solid solution have been formed by rapid solidification.

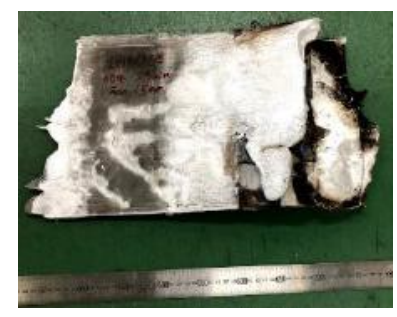

(a) $5 \mathrm{~m} / \mathrm{min}$

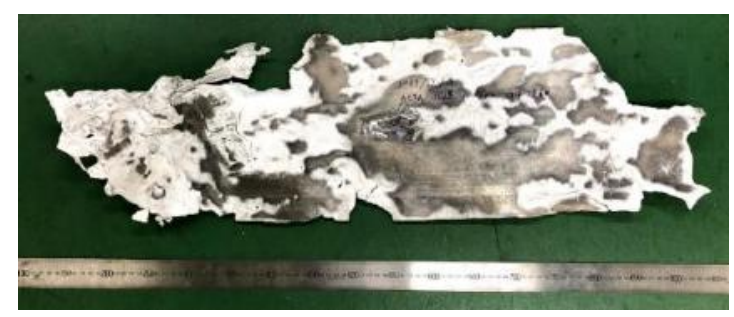

(b) $10 \mathrm{~m} / \mathrm{min}$

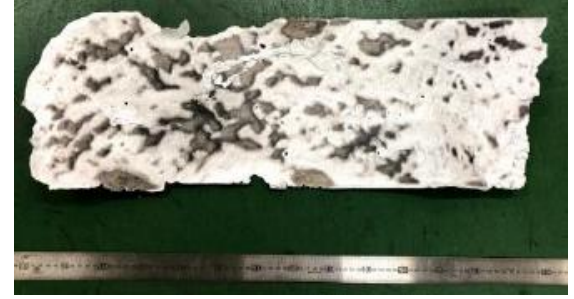

(c) $20 \mathrm{~m} / \mathrm{min}$

Fig. 6 Produced strip

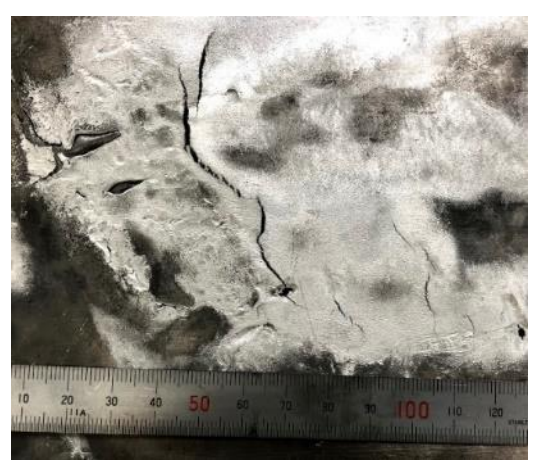

Fig. 7 Solidification crack

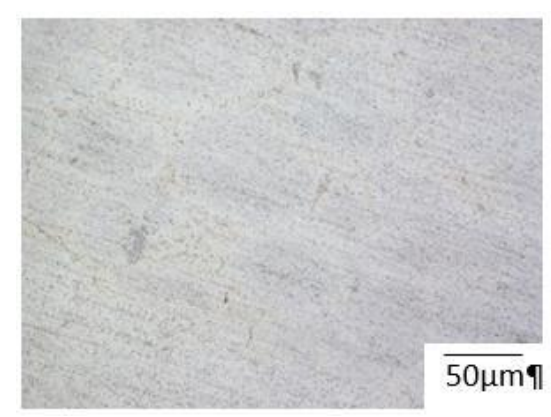

Center

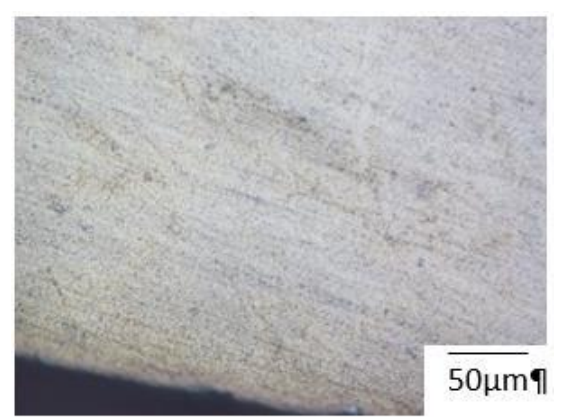

Near the surface

Fig. 8 Microstructure of the strip $(10 \mathrm{~m} / \mathrm{min})$ 
Table 2 Strip thickness and rolling load

\begin{tabular}{l|c|c|c}
\hline \hline Roll speed [m/min] & 5 & 10 & 20 \\
\hline Strip length [mm] & 174 & 764 & 665 \\
\hline Strip thickness [mm] & 2.47 & 2.01 & 1.67 \\
\hline Rolling load [t] & 75 & 34 & 41 \\
\hline
\end{tabular}

\section{CONCULUSION}

In this study, the experiments of twin roll casting of aluminum alloy AC7A using a commercial scale machine was carried out to investigate the effects of the roll speed on the continuity, surface properties and strip thickness of strips. The conclusions are as follows.

(1) When the peripheral speed was $10 \mathrm{~m} / \mathrm{min}$ and 20 $\mathrm{m} / \mathrm{min}$, the thin plate could be produced continuously.

(2) At a peripheral speed of $5 \mathrm{~m} / \mathrm{min}$, the maximum rolling load in the design was reached, and the machine stopped automatically, so that it was impossible to manufacture thin plates continuously, but metallic luster was observed on the whole surface.

(3) The solidification cracking was observed in the sheet with a peripheral speed of $10 \mathrm{~m} / \mathrm{min}$ and $20 \mathrm{~m} / \mathrm{min}$.

(4) There was a difference between initial roll gap and plate thickness. This is caused by the skill level of the equipment, and it is considered that the problem can be solved by setting the initial roll gap for the target plate thickness in consideration of the elastic deformation of the equipment.

(5) The microstructural observation suggested that a supersaturated $\alpha-\mathrm{Al}$ solid solution was formed by rapid solidification.

\section{ACKNOWLEDGEMENTS}

This study was conducted at Monodzukuri Innovation Center, Ota Campus, Gunma University. The project was supported by a grant from Ota City (MRO) to promote joint research in the Ota area, a grant from the Japan Aluminum Association and a grant from Japan Society for Technology of Plasticity.

\section{REFERENCES}

[1] Light Metal Society edition: Microstructure and properties of aluminum (1991).
[2] Engler, C. Schäfer, H. J. Brinkman, J. Brecht, P. Beiter and K. Nijhof, Journal of Materials Processing Technology, 229 (2016), 139-148.

[3] T. Haga, H. Inui, H. Watari and S. Kumai, Journal of Materials Processing Technology, 191, 1-3 (2007), 238-241.

[4] T. Haga, M. Ikawa, H. Watari and S. Kumai, Journal of Materials Processing Technology, 172, 2 (2006), 271-276.

[5] T. Haga, K. Takahashi, M. Ikawaand and H. Watari, Journal of Materials Processing Technology, 153-154 (2004), 42-47.

[6] T. Haga and S. Suzuki, Journal of Materials Processing Technology, 143-144 (2003), 895-900.

[7] Hongbin Wang, Le Zhou, Yongwen Zhang, Yuanhua Cai, Journal of Materials Processing Technology, 233 (2016), 186-191.

[8] T.Haga, K Takahashi, H Watari, S Kumai, Journal of Materials Processing Technology, 192-193 (2007), 108-113.

[9] T Haga, T Nishiyama, S Suzuki, Journal of Materials Processing Technology, 133 (2003), 103-107.

[10] T Haga, K Takahashi, Journal of Materials Processing Technology, 157-158 (2004), 701-705. 